OPEN ACCESS

Edited by:

Uwe Ritter,

University of Regensburg, Germany

Reviewed by:

Christian Bogdan,

University of Erlangen-Nuremberg,

Germany

Thomas Jacobs,

Bernhard-Nocht-Institut für

Tropenmedizin, Germany

${ }^{*}$ Correspondence:

Fabienne Tacchini-Cottier fabienne.tacchini-cottier@unil.ch

tThese authors have contributed equally to this work.

Specialty section:

This article was submitted

to Microbial Immunology,

a section of the journal

Frontiers in Immunology

Received: 10 July 2017 Accepted: 22 September 2017

Published: 10 October 2017

Citation:

Descatoire $M$, Hurrell BP, Govender M, Passelli K, MartinezSalazar B, Hurdayal R, Brombacher F, Guler R and Tacchini-Cottier F (2017)

IL-4R $\alpha$ Signaling in Keratinocytes and Early IL-4 Production Are

Dispensable for Generating

a Curative THelper 1 Response

in Leishmania major-Infected

C57BL/6 Mice.

Front. Immunol. 8:1265.

doi: 10.3389/fimmu.2017.01265

\section{IL-4Ro Signaling in Keratinocytes and Early IL-4 Production Are Dispensable for Generating a Curative T Helper 1 Response in Leishmania major-Infected C57BL/6 Mice}

\author{
Marc Descatoire ${ }^{1 \dagger}$, Benjamin P. Hurrell ${ }^{1 \dagger}$, Melissa Govender ${ }^{2,3}$, Katiuska Passelli', \\ Berenice Martinez-Salazar ${ }^{2,3}$, Ramona Hurdaya2 ${ }^{2,3,4}$, Frank Brombacher ${ }^{2,3}$, Reto Guler ${ }^{2,3}$ \\ and Fabienne Tacchini-Cottier ${ }^{1 *}$ \\ ${ }^{1}$ Department of Biochemistry, WHO-Immunology Research and Training Center, University of Lausanne, Lausanne, \\ Switzerland, ${ }^{2}$ Division of Immunology and South African Medical Research Council (SAMRC) Immunology of Infectious \\ Diseases, Faculty of Health Sciences, Institute of Infectious Diseases and Molecular Medicine (IDM), University of Cape \\ Town, Cape Town, South Africa, ${ }^{3}$ International Centre for Genetic Engineering and Biotechnology (ICGEB), Cape Town \\ Component, Cape Town, South Africa, ${ }^{4}$ Department of Molecular and Cell Biology, Faculty of Science, University of Cape \\ Town, Cape Town, South Africa
}

Experimental infection with the protozoan parasite Leishmania major has been extensively used to understand the mechanisms involved in T helper cell differentiation. Following infection, C57BL/6 mice develop a small self-healing cutaneous lesion and they are able to control parasite burden, a process linked to the development of T helper (Th) 1 cells. The local presence of IL-12 has been reported to be critical in driving Th1 cell differentiation. In addition, the early secretion of IL-4 was reported to potentially contribute to Th1 cell differentiation. Following infection with $L$. major, early keratinocyte-derived IL-4 was suggested to contribute to Th1 cell differentiation. To investigate a putative autocrine role of IL-4 signaling on keratinocytes at the site of infection, we generated C57BL/6 mice deficient for IL-4R $\alpha$ expression selectively in keratinocytes. Upon infection with L. major, these mice could control their inflammatory lesion and parasite load correlating with the development of Th1 effector cells. These data demonstrate that IL-4 signaling on keratinocytes does not contribute to Th1 cell differentiation. To further investigate the source of IL-4 in the skin during the first days after L. major infection, we used C57BL/6 $\mathrm{IL}-4$ reporter mice allowing the visualization of IL-4 mRNA expression and protein production. These mice were infected with $L$. major. During the first 3 days after infection, skin IL-4 mRNA expression was observed selectively in mast cells. However, no IL-4 protein production was detectable locally. In addition, early IL-4 blockade locally had no impact on subsequent Th1 cell differentiation and control of the disease. Taken together, the present data rule out a major role for skin IL-4 and keratinocyte IL-4R $\alpha$ signaling in the development of a Th1 protective immune response following experimental infection with L. major.

Keywords: Leishmania, IL-4, IL-4R $\alpha$, T helper cell differentiation, T helper 1, T helper 2, keratinocytes, mast cells 


\section{INTRODUCTION}

Upon infection, Leishmania protozoan parasites can cause a spectrum of diseases ranging from cutaneous, muco-cutaneous to visceral forms. Following Leishmania major experimental infection, C57BL/6 mice develop a small cutaneous lesion that is self-healing. Healing of lesion and control of parasite load were shown to result from the differentiation of $\mathrm{CD}^{+} \mathrm{T}$ helper (Th) 1 cells characterized by their secretion of high levels of IFN $\gamma$, a cytokine promoting the differentiation of M1 macrophages that kill intracellular parasites. In contrast, following L. major infection, $\mathrm{BALB} / \mathrm{c}$ mice develop non-healing lesions and are not able to control their parasite load. This phenotype was shown to correlate with the development of CD4 ${ }^{+}$Th2 cells secreting IL- 4 and IL-13 cytokines $(1,2)$. These cytokines induce the differentiation of M2 macrophages that favor parasite survival within macrophages (3). The L. major experimental model was the first murine model demonstrating that the discovery of Th1 and Th 2 cells subsets by Mosmann et al. in vitro (4) had some relevance in vivo.

It is well established that the IL-12 produced by antigen presenting cells (APC) is necessary to launch the differentiation of $\mathrm{CD}^{+}$Th1 cells that protect against intracellular pathogens, including Leishmania (5). In contrast the role of IL-4 in L. major susceptibility and Th2 cell differentiation is more controversial. Following infection with L. major (LV39), IL-4 ${ }^{-/-}$or IL-4R $\alpha^{-/-}$ mice on a BALB/c genetic background were able to control lesion size and the levels of IFN $\gamma$ present in draining lymph node (dLN) cells was either very low or remained unchanged compared to that observed in BALB/c wild-type mice $(6,7)$. These data suggested that IL-4 was critical for L. major susceptibility and Th2 cell differentiation. The $\mathrm{C} 57 \mathrm{Bl} / 6 \times 129 \mathrm{IL}-4^{-1-}$ mice used in these studies were backcrossed for six generations onto the BALB/c genetic background. In contrast, following infection with L. major LV39 IL-4 ${ }^{-/-}$mice generated with embryonic stem cells of BALB/c origin still developed progressive non-healing lesions that were comparable to those of similarly infected wild-type $\mathrm{BALB} / \mathrm{c}$ mice (8). Infection of these mice with another strain of $L$. major (IR173) resulted in partial control of lesion size in IL- $4^{-/-}$mice, while IL-4R $\alpha^{-/-}$controlled lesion size efficiently (9). Additional studies using IL- 4 or IL- $4 \mathrm{R} \alpha$-deficient mice showed that following infection with $L$. major Th2 differentiation could develop in absence of IL-4 (10-12). Specific deletion of IL-4R $\alpha$ signaling on $\mathrm{T}$ cells resulted in a healing phenotype in BALB/c mice associated with increased IFN $\gamma$ response, suggesting a role for IL-4 and IL-13 in susceptibility following L. major infection (13). Collectively, these results indicated that along with IL-4, IL-13, and other factors are involved in the control of Th2 cell differentiation and L. major susceptibility (14).

In addition, several lines of evidence suggest that IL-4 may be needed for Th1 cell differentiation. Unlike what was observed following L. major infection, IL-4-deficient mice failed to develop Th1 cells in response to infection with Candida albicans (15) suggesting a potential role for endogenous IL-4 in Th1 cell differentiation and protective antifungal response. Furthermore, local injection of exogenous recombinant IL- 4 within the first $8 \mathrm{~h}$ of $L$. major infection in BALB/c mice was sufficient to modify the development of the immune response from an otherwise Th2 immune response into a protective type-1 Th1 response (16). It was hypothesized that IL-4, by acting on dendritic cells, induced their IL-12 secretion (16), a process that had previously been reported on macrophages and DCs in vitro (17-19). In addition, dendritic cell-specific IL-4R $\alpha$-deficient mice on the BALB/c genetic background developed larger lesions and increased Th2 response, suggesting some protective role for endogenous IL-4 acting on DCs during L. major LV39 and IL-81 infection (20). Collectively, these studies suggested that within the first hours of $L$. major infection the transient presence of IL-4 could contribute to the differentiation of $\mathrm{CD}^{+} \mathrm{Th} 1$ cells. In this line, skin keratinocytes present in the footpad of mice infected with L. major subcutaneously were identified as an early IL-4 source contributing to the launching of $\mathrm{CD}^{+}$Th1 cell differentiation (21). Interestingly, in that study, IL- 4 transcription appeared restricted to keratinocytes from $\mathrm{C} 57 \mathrm{BL} / 6$ mice and only low IL-4 mRNA levels were observed in BALB/c keratinocytes. Moreover, in the same study, the upregulation of IL- 4 mRNA observed in C57BL/6 keratinocytes was shown to be restricted to a very small time window at the onset of infection. Finally, impaired Th1 cell development was observed in C57BL/6 mice following blocking of IL- 4 protein with an anti-IL- $4 \mathrm{mAb}$ at the cutaneous infection site (21). Targeting IL-4 at the infection site could be of potential interest in the design of vaccines.

Here, we investigated the role of skin IL- $4 \mathrm{R} \alpha$ signaling, more specifically the contribution of keratinocyte-derived IL- $4 \mathrm{R} \alpha$ signaling during the first days of $L$. major infection and its subsequent impact on the development of a protective type- 1 immune response in $\mathrm{C} 57 \mathrm{BL} / 6$ mice. To this end, we generated C57BL/6 mice specifically deficient in IL-4R $\alpha$ in their keratinocytes (KRT14 ${ }^{\text {Cre }}$ IL-4R $\left.\alpha^{-/ l o x}\right)$. As IL-4 and IL-13 share a common signaling pathway through the IL- $4 \mathrm{R} \alpha$ the combined role of both cytokines could be studied in these mice. Following infection with $L$. major in the ear dermis or subcutaneously in the footpad, these mice were fully able to control their lesion size and develop Th1 cells. Furthermore, using IL-4 reporter mice, we identified mast cells as the only skin cells transcribing but not producing IL-4 in C57BL/6 skin early in infection. Our data demonstrate that the presence of IL-4 and IL- 4 signaling in the skin during the first days after $L$. major infection are not required for the development of a protective Th1 immune response in $\mathrm{C} 57 \mathrm{BL} / 6$ mice.

\section{MATERIALS AND METHODS}

\section{Mice}

C57BL/6 mice were purchased from Charles Rivers. 4get, and KN2 mice $(22,23)$ were a gift from Markus Mohrs, Trudeau Institute, USA. Keratinocyte cell-specific 4get/KN2 mice were obtained by the breeding of 4get and KN2 mice. IL-4R $\alpha$-deficient (KRT14 ${ }^{\text {cre }} \mathrm{IL}-4 \mathrm{R} \alpha^{-/ \mathrm{lox}}$ ) mice on the $\mathrm{C} 57 \mathrm{BL} / 6$ genetic background were generated using the Cre/loxP system. Briefly, KRT14 ${ }^{\text {cre }}$ mice on the BALB/c genetic background (Jackson Laboratory) were first backcrossed on the C57BL/6 genetic background for nine generations. The progeny were crossed with IL- $4 \mathrm{R} \alpha^{-/-}$ C57BL/6 mice and transgenic IL-4R $\alpha^{\text {lox/lox }}$ mice (24) to generate 
hemizygous KRT14 ${ }^{\text {cre }}$ IL-4R $\alpha^{-/ l o x}$ C57BL/6 mice. Genotyping of KRT14 ${ }^{\text {cre } I L-4 R \alpha^{-/ l o x}}$ C57BL/6 mice was performed using specific primers: KRT14 P1, 5'- TTC CTC AGG AGT GTC TTC GC; KRT14 P2, 5' - GTC CAT GTC CTT CCT GAA GC; KRT14 P3, 5'- CAA ATG TTG CTT GTC TGG TG; KRT14 P4, 5' - GTC AGT CGA GTG CAC AGT TT. Characterization was also performed by flow cytometry using the anti-IL- $4 \mathrm{R} \alpha \mathrm{mAb}$ [anti-CD124, anti-IL-4R $\alpha$-PE from (BD, Pharmingen)]. Mice were bred under pathogen-free conditions at the Epalinges Center. 5- to 8-weekold females were used.

\section{Ethics Approval}

All animal experimental protocols were approved by the veterinary office regulations of the State of Vaud, Switzerland, authorization 1266.6-7 to FTC and performed in compliance with Swiss ethics laws for animal protection. All mouse experiments performed at the University of Cape Town were performed in strict accordance with the South African national guidelines, as well as the Animal Research Ethics Committee of the Faculty of Health Sciences, University of Cape Town (license no. 015/034). All efforts were made to minimize and reduce suffering of animals.

\section{Parasites and Infections}

Leishmania major (LV39, MRHO/Sv/59/P strain) or in selected experiments GFP-expressing L. major IL-81 (MHOM/IL/81/ FEBNI) parasites were cultured at $26^{\circ} \mathrm{C}$ in complete M199 medium ( $10 \%$ fetal bovine serum, $4 \%$ HEPES, $1 \%$ penicillin, streptomycin, and neomycin). $10^{4}$ or $2 \times 10^{5}$ L. major metacyclic promastigotes were prepared from confluent stationary phase promastigotes by Ficoll gradient density centrifugation as previously described (25) and injected in the ear dermis or footpad. Lesion development was monitored using Vernier caliper, ear lesion diameter was measured for intradermal infection. For IL-4 depletion, $2 \times 10^{5}$ metacyclic parasites $( \pm 1 \mu \mathrm{g} 11 \mathrm{~B} 11$ antibody) were needle injected into the ear dermis in iDMEM in a final volume of $10 \mu \mathrm{L}$, or in the hind footpad in a volume of $50 \mu \mathrm{L}$. Four hours later, $1 \mu \mathrm{g}$ of $11 \mathrm{~B} 11 \mathrm{mAb}$ was injected intradermally (i.d.) in a final volume of $10 \mu \mathrm{L}$. For the induction of a Th2 response in C57BL/6 4get/KN2 mice, $1 \mathrm{mg}$ of $\alpha \mathrm{IFN} \gamma$ (XMG1.2) and $\alpha \mathrm{IL}-12$ were injected intraperitoneally $24,2 \mathrm{~h}$ prior and $48 \mathrm{~h}$ post intradermal infection of $2 \times 10^{5} \mathrm{~L}$. major metacyclic promastigotes.

\section{Determination of Antibody Response}

Leishmania major-specific IgG1 and IgG2c levels were determined by ELISA in the sera of mice harvested at the termination of the experiment, as previously described (26), Biotinylated goat anti-mouse IgG2c (Southern Biotech) and biotinylated rat anti-mouse IgG1 (BD Pharmingen) were used. Plates were read at the optical density of $490 \mathrm{~nm}$. Titration curve were performed for all samples.

\section{Isolation of dLN, Spleen, and Ear Mouse Cells}

Infected ears, spleen, and dLNs were isolated and processed to single cell suspensions. Briefly, ears were recovered, homogenized in iDMEM containing $0.2 \mathrm{mg} / \mathrm{mL}$ Liberase TL (Roche) for $2 \mathrm{~h}$ at $37^{\circ} \mathrm{C}$ and then homogenized and filtered using $40-\mu \mathrm{m}$ filters (Falcon). dLN and spleen cells were isolated, homogenized, and stained for flow cytometry analysis. For intracellular cytokine staining, $1 \times 10^{6} \mathrm{dLN}$ cells were stimulated with $50 \mu \mathrm{g} / \mathrm{mL}$ PMA, $500 \mu \mathrm{g} / \mathrm{mL}$ Ionomycin, and $1 \mu \mathrm{g} / \mathrm{mL}$ Brefeldin A for $4 \mathrm{~h}$ prior staining. Live parasites were determined by limiting dilution assay (LDA) as described previously (27).

\section{Cytokine Production}

$10^{6} \mathrm{dLN}$ cells were cultured in presence or absence of UVirradiated stationary phase parasites (parasites were exposed to UV.C for $3 \mathrm{~min}$, at a distance of $10 \mathrm{~cm}$ from the UV lamp) L. major promastigotes (MOI of 5:1) for $72 \mathrm{~h}$ at $37^{\circ} \mathrm{C}$. Supernatants were recovered and IL- 4 production measured by ELISA following manufacturer's instructions (BD Biosciences; R\&D). IFN $\gamma$ secretion was detected using a homemade ELISA kit as previously described (28).

\section{Derivation of Mouse Primary Keratinocytes}

Primary keratinocytes were isolated from the skin of adult mice tail. Briefly, the skin from the tail was collected and incubated at $4^{\circ} \mathrm{C}$ for $16 \mathrm{~h}$ in a solution of $5 \mathrm{U} / \mathrm{mL}$ Dispase (STEMCELL) supplemented with 1\% PNS (Gibco) and 0.5\% Gentamicin (Gibco). The epidermis was separated from the dermis and treated with $0.2 \%$ trypsin (Gibco) for $5 \mathrm{~min}$ at $37^{\circ} \mathrm{C}$. The reaction was stopped with FCS, and cells were collected by crushing the epidermis with a $100-\mu \mathrm{m}$ cell strainer (Falcon). $7.5 \times 10^{5}$ cells/ $\mathrm{mL}$ were plated in a 6 -well plate coated with Type I collagen (STEMCELL). Cells were grown for 8 days at $37^{\circ} \mathrm{C}$ in CnT-57.S medium (CELLnTEC) supplemented with $1 \%$ PNS and $0.5 \%$ Gentamicin. Medium were removed and cells detached with $200 \mu \mathrm{L} 0.2 \%$ trypsin for $5 \mathrm{~min}$ at $37^{\circ} \mathrm{C}$. Cells were counted and plated at $0.3 \times 10^{6}$ cells $/ \mathrm{mL}$ in a 96 -well plate coated with Type I collagen.

\section{Flow Cytometry}

Stained cells were analyzed using a BD LSR II-SORP or Fortessa system (Becton Dickinson) and analyzed with FlowJo software (Tree Star). The following anti-mouse mAbs were used: CD45- PerCPCy5, CD45-APC, CD8-APC, anti-IFN $\gamma$-PECy7, and anti-IL-4-FITC (BD Biosciences), CD4-AF700, CD11b APC-eFluor780, and c-kit PECy7 all from (eBiosciences). Anti human CD2 (BioLegend) was used to detect IL-4 production in $\mathrm{KN} 2$ mice. To detect IL-4R $\alpha$ on primary keratinocytes, the following anti-mouse mAbs were used: CD124, anti IL-4R $\alpha-\mathrm{PE}$ (BD, Pharmingen), and CD49f-Brillant Violet 421 (BioLegend). Imaging flow cytometry was performed using an ImageStream cytometer (Amnis, Millipore) at low speed. Data were analyzed with the IDEAS software.

\section{Statistics}

All $p$ values were determined with Prism software (GraphPad Software, Inc.) using the Student's $t$-test for unpaired data or paired data, following prior testing for normal distribution. The degree of significance was indicated as ${ }^{\star} p<0.05$, ${ }^{* *} p<0.01$, and ${ }^{* * *} p<0.001$. 


\section{RESULTS}

\section{Absence of IL-4R $\alpha$ Signaling in Keratinocytes Does Not Prevent the Development of a Protective Type-1 Immune Response}

To investigate the impact of IL- $4 \mathrm{R} \alpha$ signaling on keratinocytes in a protective Th1 cell differentiation against cutaneous leishmaniasis, we generated mice on the $\mathrm{C} 57 \mathrm{BL} / 6$ genetic background that are genetically deficient in IL- $4 \mathrm{R} \alpha$ expression on keratinocytes (KRT14 ${ }^{\text {Cre }} \mathrm{IL}-4 \mathrm{R} \alpha^{-/ l o x}$ ) using the Cre/LoxP recombination system under control of the KRT14 locus. In these mice, keratinocytes cannot respond to IL-4 and IL-13, while other cells can. The absence of skin IL- $4 \mathrm{R} \alpha$ expression was verified by PCR of naïve ears. KRT14 ${ }^{\text {Cre }} \mathrm{IL}-4 \mathrm{R} \alpha^{-/ \text {lox }}$ expressed both the deleted and WT IL-4R $\alpha$ allele in addition to the LoxP and Cre bands. The genotype was also validated for IL-4R $\alpha^{-/ l o x}, \mathrm{IL}-4 \mathrm{R} \alpha^{+/+}$ (C57BL/6 wild type) control mice as well as for IL- $4^{-/-}$on the
C57BL/6 genetic background (Figure 1A). The selective absence of IL-4R $\alpha$ on $\mathrm{KRT} 14^{\mathrm{Cre}} \mathrm{IL}-4 \mathrm{R} \alpha^{-/ l o x}$ keratinocytes was further analyzed by flow cytometry on primary keratinocytes derived from the skin of these mice. IL-4R $\alpha$ expression was not detected on $\mathrm{CD}_{4} 5^{-} \mathrm{CD} 49 \mathrm{f}^{+}$keratinocytes of KRT14 ${ }^{\text {Cre }} \mathrm{IL}-4 \mathrm{R} \alpha^{-/ \text {lox }}$ mice. As controls, expression of IL- $4 \mathrm{R} \alpha$ was detected on keratinocytes of wild-type C57BL/6 mice and was absent on keratinocytes of IL- $4 \mathrm{R} \alpha^{-/-}$mice (Figure 1B). As expected, expression of IL- $4 \mathrm{R} \alpha$ was, however, detected in splenic $\mathrm{CD} 4^{+} \mathrm{T}$ cells, $\mathrm{CD} 19^{+} \mathrm{B}$ cells, and $\mathrm{F} 480^{+}$macrophages of KRT14 ${ }^{\mathrm{Cr}} \mathrm{IL}-4 \mathrm{R} \alpha^{-/ \mathrm{lox}}$ mice (Figure 1C). The slightly lower IL-4R $\alpha$ surface expression levels observed in $\mathrm{KRT} 14^{\text {Cre }} \mathrm{IL}-4 \mathrm{R} \alpha^{-/ \text {lox }} \mathrm{CD} 4^{+} \mathrm{T}$ cells, $\mathrm{CD} 19^{+} \mathrm{B}$ cells and $\mathrm{F} 480^{+}$ macrophages compared to those observed in C57BL/6 wild-type cells are in line with the IL- $4 \mathrm{R} \alpha^{-/ l o x}$ genotype of the control mice. No IL-4R $\alpha$ expression was observed in IL-4R $\alpha^{-/-} \mathrm{CD} 4^{+} \mathrm{T}$ cells and $\mathrm{CD} 19^{+} \mathrm{B}$ cells. These data show that KRT14 ${ }^{\mathrm{Cre}} \mathrm{IL}-4 \mathrm{R} \alpha^{-/ 10 x}$ mice do not express IL- $4 \mathrm{R} \alpha$ selectively on keratinocytes.

To investigate if IL- $4 \mathrm{R} \alpha$ signaling in keratinocytes could have an impact on the local microenvironment driving Th1 differentiation

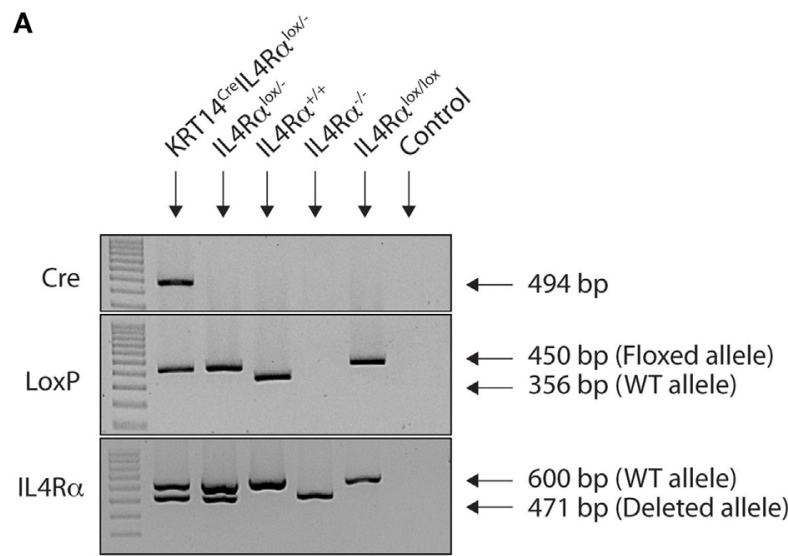

B
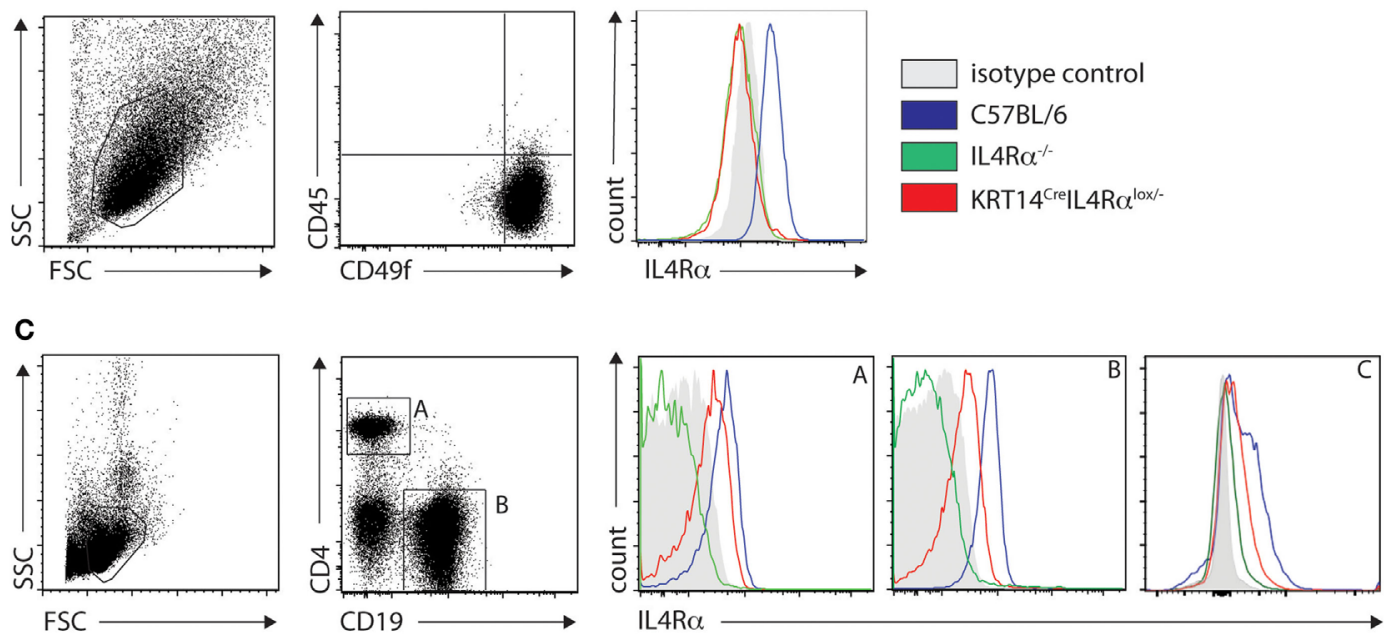

FIGURE 1 | Characterization of KRT14 $4^{\text {crel L-4R }} \alpha^{-10 x}$ C57BL/6 mice. (A) Genotyping of KRT14 $4^{\text {crellL-4R }} \alpha^{-10 x}$ mice, IL-4R $\alpha^{-10 x}$, IL-4R $\alpha^{+/+}$, IL-4R $\alpha^{\text {lox/lox }}$, and negative control $\left(\mathrm{H}_{2} \mathrm{O}\right)$ is shown. The yielded PCR products in base pairs are indicated in the figure. (B) IL-4R $\alpha$ cell surface expression was analyzed by flow cytometry on primary keratinocytes of the indicated mice. (C) IL-4Ro expression was analyzed in splenic CD4+ $T$ cells (A), CD19+ B cells (B) and F480+ $(C)$ macrophages of the indicated mice. Data shown are representative of three independent experiments. 
during L. major infection, KRT14 ${ }^{\text {Cre }} \mathrm{IL}-4 \mathrm{R} \alpha^{-/ l o x}$ on the C57BL/6 genetic background were infected subcutaneously in the footpad with $2 \times 10^{5} \mathrm{~L}$. major. Lesion development and parasite load in the dLNs and spleen were analyzed and compared to lesion developing in control IL- $4 \mathrm{R} \alpha^{-/ l o x}, \mathrm{IL}-4 \mathrm{R} \alpha^{+/+}$, and IL- $4 \mathrm{R} \alpha^{-/-}$mice all on the C57BL/6 genetic background. L. major susceptible BALB/c mice were similarly infected and used for comparison. No difference in lesion development was observed between all groups of mice on the $\mathrm{C} 57 \mathrm{BL} / 6$ genetic background, and $\mathrm{BALB} / \mathrm{c}$ mice developed a significantly larger lesion (Figure 2A). Parasite load was also similar in the dLNs of these mice and no parasite dissemination to the spleen was observed, while significantly higher dLN parasite load and the presence of parasite dissemination to the spleen were observed in BALB/c mice (Figures 2B,C). Phlebotomine sand flies deposit significantly lower dose of parasites in the mammalian dermis, and it was previously reported that the cellular recruitment differ between subcutaneous infection in the footpad or intradermal infection in mouse ear dermis (29). To assess a potential role for IL-4R $\alpha$ signaling in keratinocytes on disease outcome in more physiological conditions, we needle inoculated mice with $1 \times 10^{4}$ L. major LV39 metacyclic parasites, in the ear dermis of KRT14 ${ }^{\text {Cre IL- }} 4 \mathrm{R}^{-/ \text {lox }}$ mice. Lesion development and parasite load were compared to those observed in similarly infected IL- $4 \mathrm{R} \alpha^{-/ l o x}$, IL- $4 \mathrm{R} \alpha^{-/-}$mice, IL-4R $\alpha^{+/+}$mice all on the C57BL/ 6 genetic background. No difference in lesion size was observed in all groups of mice. In contrast, similarly infected BALB/c mice developed nonhealing lesions (Figure 2D). All groups of mice on the C57BL/6 genetic background also controlled parasite load as assessed in the dLN and no parasite dissemination to the spleen was observed while similarly infected BALB/c mice showed higher parasite load in $\mathrm{dLN}$ and parasite disseminated to the spleen (Figures 2E,F). These data demonstrate that IL- $4 \mathrm{R} \alpha$ signaling in keratinocytes is not required for control of lesion development and parasite burden. In addition, total lack of IL- $4 \mathrm{R} \alpha$ signaling did not have an impact on the resolution of the infection. The control of parasite load in KRT14 ${ }^{\text {Cre }} \mathrm{IL}-4 \mathrm{R} \alpha^{-/ l o x}$ and IL- $4 \mathrm{R} \alpha^{-/-}$mice suggested that an efficient protective Th1 immune response could develop in these mice in absence of IL- $4 \mathrm{R} \alpha$ signaling.

\section{Mice Deficient in IL-4R $\alpha$ Signaling in Keratinocytes Are Capable to Mount a Th1 Cell Response following $L$. major Infection}

To further investigate in details if IL- $4 \mathrm{R} \alpha$ signaling in keratinocytes impacted Th1 cell differentiation during cutaneous leishmaniasis, KRT14 ${ }^{\text {Cre }}$ IL- $4 \mathrm{R} \alpha^{-/ \text {lox }}$ mice and control IL- $4 \mathrm{R} \alpha^{-/ \text {lox }}$ were infected with $10^{4}$ L. major (LV39). Four weeks after infection, the frequency of IFN $\gamma$ and IL-4 producing cells was analyzed by flow cytometry at the site of infection. A high frequency of CD $4^{+} \mathrm{IFN} \gamma^{+}$ was detected in the ear dermis of KRT14 ${ }^{\text {Cre }} \mathrm{IL}-4 \mathrm{R} \alpha^{-/ l o x}$ mice, with no difference compared to that measured in similarly infected IL-4R $\alpha^{-/ l o x}$ control mice (Figure 3A). Only very low levels of $\mathrm{CD} 45^{+} \mathrm{CD} 4{ }^{+} \mathrm{IL}-4^{+}$cells were detected in both groups (Figure $3 \mathrm{~B}$ ). The frequency of $\mathrm{CD} 4^{+} \mathrm{IFN} \gamma^{+}$cells observed in dLN cells of both groups of mice was also similar (Figure 3C) and more elevated than the frequency of $\mathrm{CD} 45^{+} \mathrm{CD} 4^{+} \mathrm{IL}-4^{+}$cells observed in $\mathrm{dLN}$ cells (Figure 3D) revealing that the $\mathrm{CD} 4^{+} \mathrm{Th} 1$ cells are able to differentiate in absence of IL- $4 \mathrm{R} \alpha$ signaling in keratinocytes.

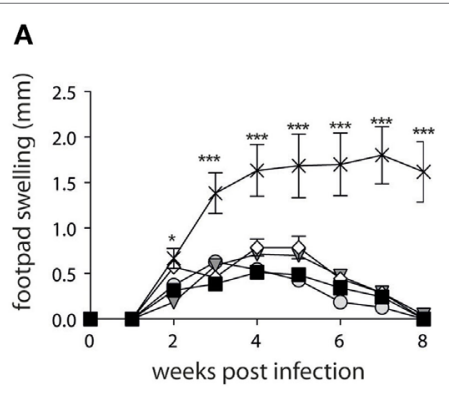

D

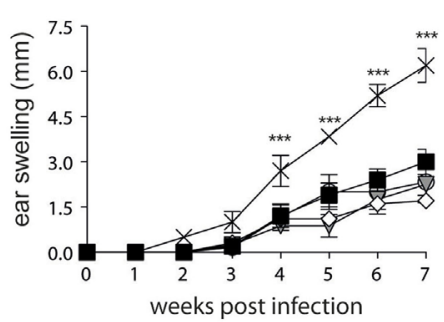

B

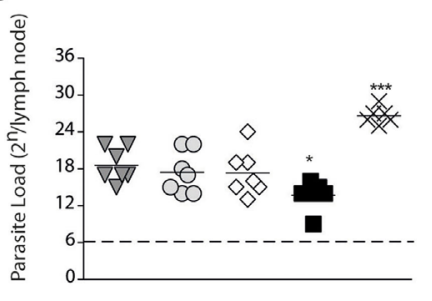

E

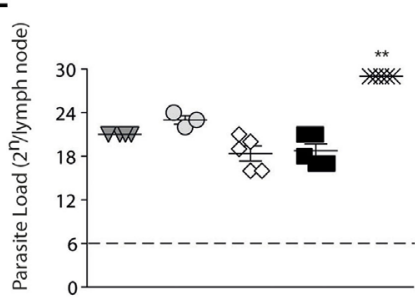

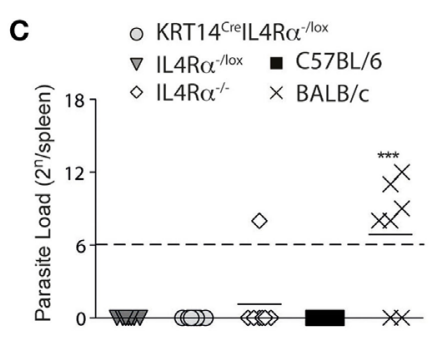

$\mathbf{F}$

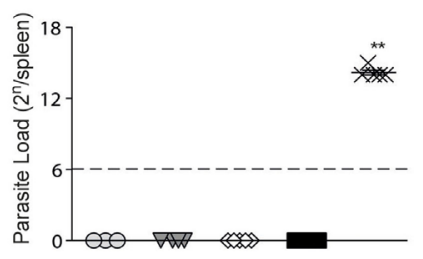

FIGURE 2 | Mice on a C57BL/6 genetic background that are deficient for IL-4Ro in their keratinocytes or on all cells are fully able to control their lesion size and

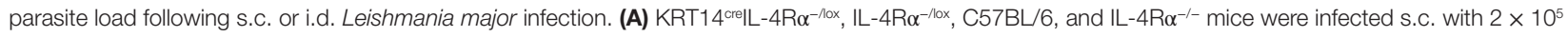
metacyclic L. major LV39 and lesion size was monitored. (B) Parasite load in draining lymph nodes (dLNs) and (C) spleen was analyzed by limiting dilution assays (LDAs) 8 weeks postinfection. (D) The indicated mice were infected in the ear dermis with $10^{4} \mathrm{~L}$. major and lesion development monitored. (E) Parasite load in the $\mathrm{dLN}$ or $(\mathbf{F})$ spleen was analyzed by LDAs 7 weeks postinfection ${ }^{* \star} p<0.01{ }^{\star * *} p<0.001$ compared to BALB/c. ${ }^{*} p<0,05$ C57BL/6 compared to IL-4R $\alpha^{-1 / 0 x}$, $\mathrm{IL}-4 \mathrm{R} \alpha^{-/-}$, and $\mathrm{KRT} 14^{\mathrm{cre}} \mathrm{L}-4 \mathrm{R} \alpha^{-1 / 0 x}$. These data are representative of two independent experiments. 

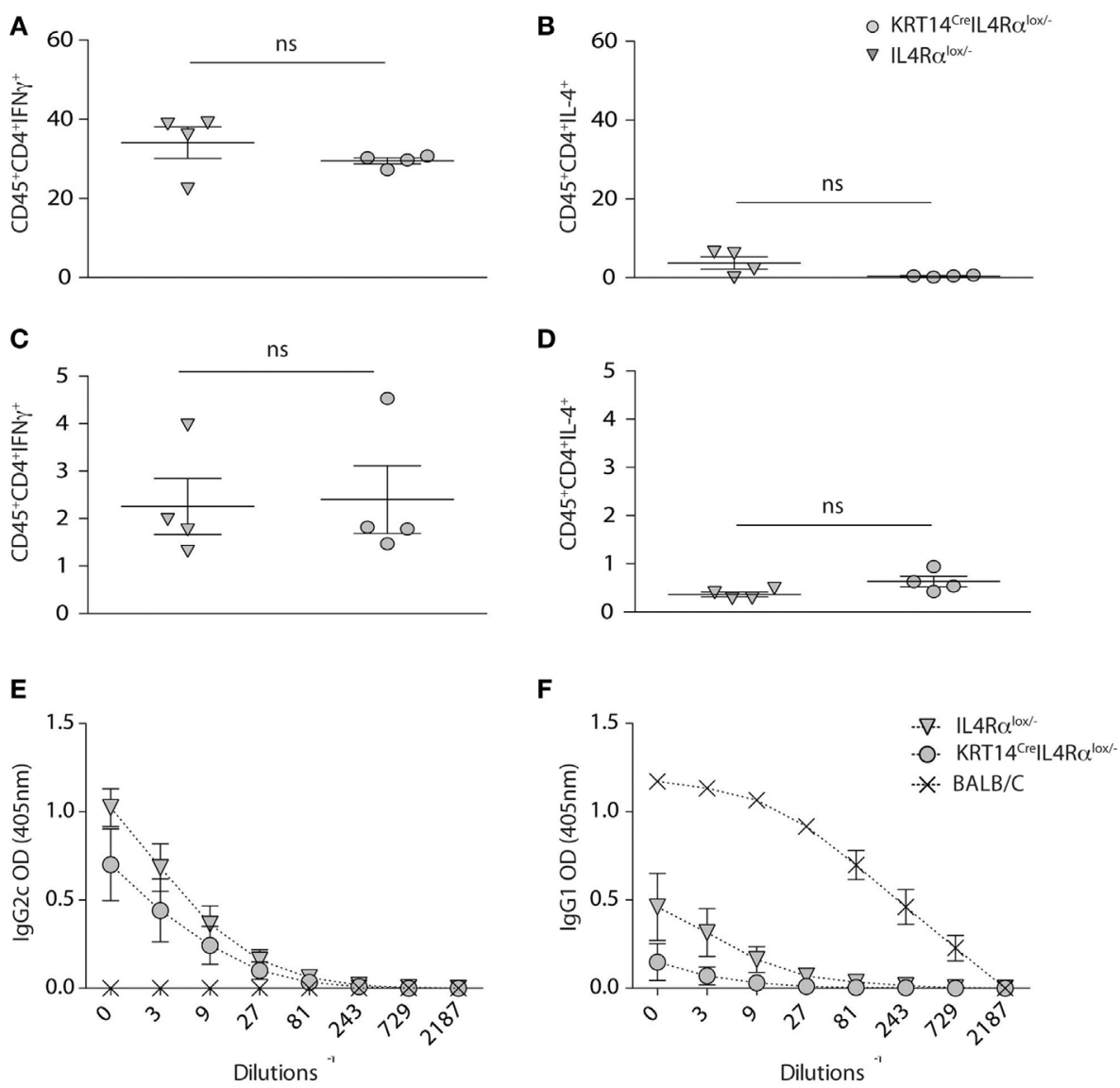

FIGURE 3 | Absence of IL-4R $\alpha$ signaling selectively on keratinocytes does not impair T helper (Th) 1 cell differentiation. (A,B) KRT14 ${ }^{\text {cre }}$ (L-4R $\alpha^{-/ / 0 x}$, IL-4R $\alpha^{-/ 10 x}$ were infected i.d. in the ear pinna with $10^{4}$ Leishmania major parasites in the ear dermis. Seven weeks postinfection, the frequency of CD4+IFN $\gamma^{+}$and $\mathrm{CD} 4^{+} \mathrm{IL}-4^{+} \mathrm{T}$ cells at the site of infection (ears) was analyzed by flow cytometry. (C,D) Similar analysis was performed on draining lymph node cells at the same time point p.i. (E) Serum from these mice was analyzed and compared to that of BALB/C mice similarly infected for the presence of $L$. major-specific IgG2C and (F) IgG1. Data shown are representative of two independent experiments.

In line with the elevated levels of IFN $\gamma$ detected at the site of infection and in dLN cells, high levels of serum IgG2c were observed in KRT14 ${ }^{\mathrm{Cre}} \mathrm{IL}-4 \mathrm{R} \alpha^{-/ \text {lox }}$ and control IL-4R $\alpha^{- \text {llox }}$ mice (Figure 3E). BALB/c mice showed elevated levels of IgG1, correlating with the high production of IL- 4 observed in their $\mathrm{CD} 4^{+} \mathrm{T}$ cells, while sera from KRT14 ${ }^{\text {Cre }} \mathrm{IL}-4 \mathrm{R} \alpha^{-/ \text {lox }}$ and control mice did not show significant IgG1 levels (Figure 3F), in line with the absence of Th2 cells detected in dLN and at the site of infection. Similar data were obtained following s.c. infection in the footpads with a higher dose of parasites $\left(2 \times 10^{5} \mathrm{~L}\right.$. major, data not shown). Taken together, these results show that the absence of IL- $4 \mathrm{R} \alpha$ signaling in keratinocytes does not impair the development of a protective Th1 type of immune response during early L. major infection.

\section{Detection of IL-4 Expressing Cells in the Ear Dermis of C57BL/6 Mice 1 Day after L. major Infection}

The lack of impact of IL-4R $\alpha$ signaling on lesion development, parasite control, and the differentiation of $\mathrm{CD} 4^{+}$Th1 cells at the site of infection and in the dLN firmly demonstrated that IL-4 signaling on keratinocytes was not involved in Th1 cell differentiation following $L$. major infection. However, it did not rule out an early role for keratinocyte-derived IL- 4 in Th1 cell differentiation. To visualize the presence of $i l-4$ mRNA expressing cells in the mouse ear dermis cells of $L$. major-infected mice, we used the bicistronic IL- 4 reporter (4get) mice on the C57BL/6 genetic background (22). We first determined if $i l-4$ mRNA expression was detectable in naive ear skin of C57BL/6 mice. A clear e-GFPpositive population was observed selectively in the $\mathrm{CD} 45^{+}$hematopoietic population. These cells did not express CD11b at their cell surface and stained positive for c-kit, a marker specific for mast cells (Figure 4A). Further analysis by imaging flow cytometry confirmed that the e-GFP il-4-expressing cells corresponded to mast cells characterized by the expression of CD45, the lack of expression of CD11b, their large size (average of $14.5 \mu \mathrm{m}$ of diameter) and the presence of numerous granules (Figure 4B). We then analyzed the modulation of il-4 mRNA expressing cells 4 and $16 \mathrm{~h}$ following i.d. infection with $L$. major, at a time when expression of $i l-4$ mRNA by keratinocytes was reported to be the highest following subcutaneous infection in the footpad (21). No e-GFP ${ }^{+}$cells were detectable in the CD45-negative 


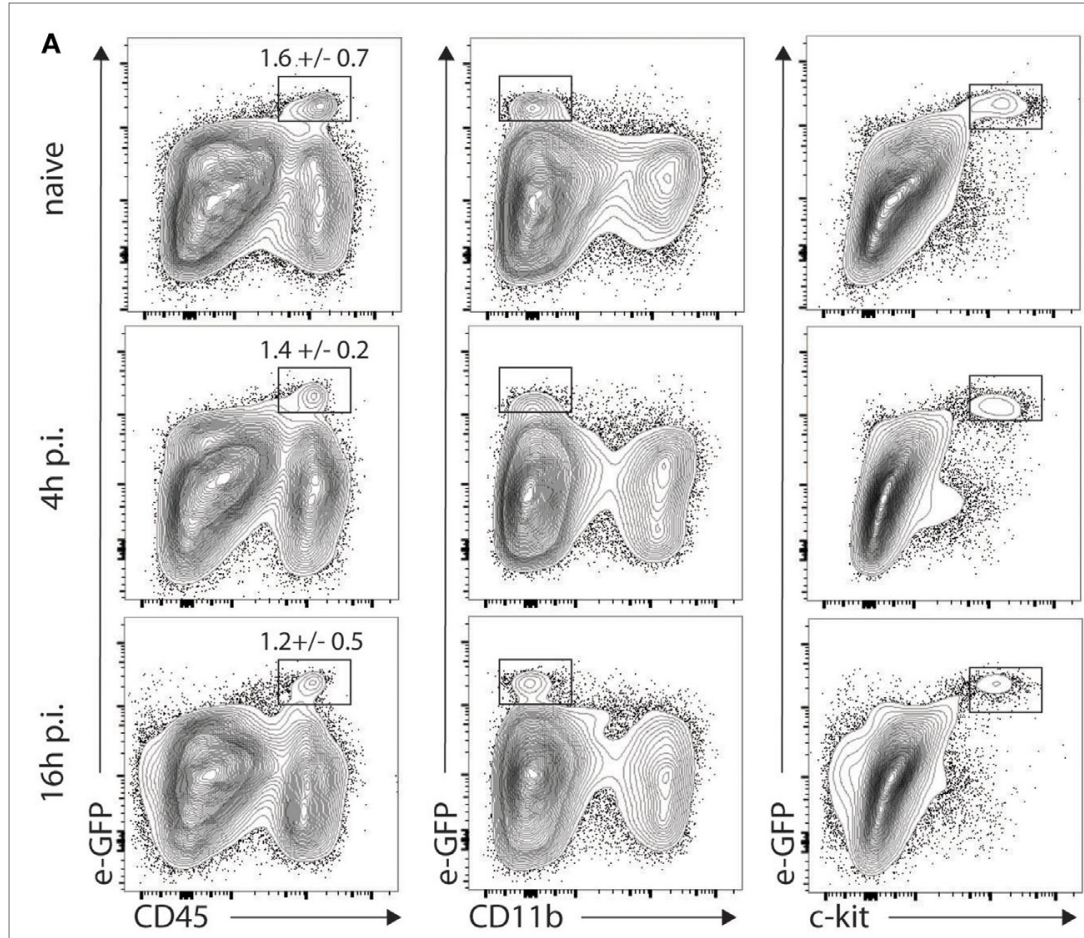

B
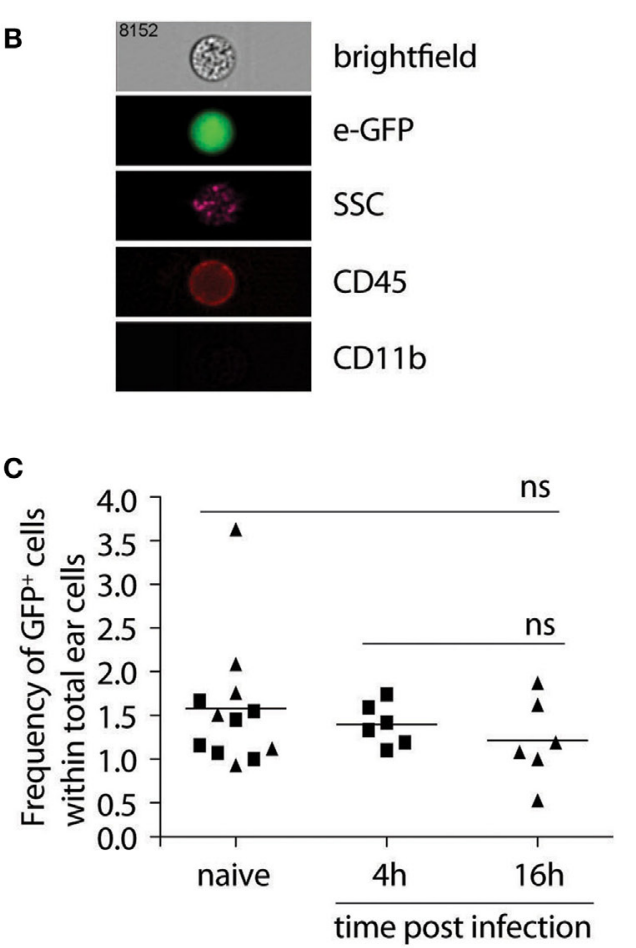

FIGURE 4 | Mast cells express il-4 in naive and Leishmania major-infected ears of C57BL/6 mice. (A) C57BL/6 4get mice were inoculated i.d. into the right ear with $2 \times 10^{5}$ metacyclic L. major. Ears were recovered 4 or $16 \mathrm{~h}$ p.i. processed and analyzed by flow cytometry for e-GFP, CD45, CD11b and c-kit surface expression. As negative controls, naïve ears were also isolated and similarly processed (B). Four hours postinfection, ears were similarly processed, stained with CD45 and CD11b, and analyzed by imaging flow cytometry. The e-GFP positive cells were all CD45+CD11b-, and showed a high granulosity (SSC) and a bright field phenotype typical of mast cells. A representative picture is shown. n.s: non-significant. (C) Frequency of e-GFP positive cells among total ear cells for 4 get C57BL/6 at 0 (naïve), 4, or $16 \mathrm{~h}(\mathbf{A})$ p.i. The data are pooled from three independent experiments.

cell population, suggesting that keratinocytes did not express detectable levels of il-4 mRNA at the time analyzed. Mast cells were the only cell population where $i l-4$ mRNA, as assessed by e-GFP expression, was detectable 4 and $16 \mathrm{~h}$ p.i. (Figure $4 \mathrm{~A}$ lower panels). The frequency of e-GFP ${ }^{+}$cell (approximately $1.5 \%$ of total ear cells) between infected and the contralateral uninfected ear was analyzed for each mouse. It did not vary between infected and uninfected ears at the analyzed time points (Figure 4C). These data show that most of the il-4 mRNA expressing cells in the ear during the first $16 \mathrm{~h}$ post infection are mast cells and that L. major does not modulate $i l-4$ mRNA expression in these cells early during infection.

\section{Mast Cells Do Not Produce IL-4 upon L. major Infection}

Mast cells appeared to be the major dermal cells expressing IL-4 early after infection, suggesting that this source of IL- 4 could play a role locally. To visualize IL-4 cytokine production, C57BL/6 KN2 (knockin huCD2) IL-4 reporter mice that specifically report the production of IL-4 protein were used. Cells producing IL-4 express a fragment of the human CD2 molecule at the cell surface making it easily detectable by flow cytometry (23). We crossed these KN2 mice with 4get mice to simultaneously detect IL-4 expression and production. First, to ensure that digestion of the ear would not impact IL-4 detection, KN2/4get mice, all on the C57BL/6 genetic background, were treated with anti-IFN $\gamma$ and anti-IL-12 mAbs at the onset of infection to induce Th2 cell differentiation. Four weeks post infection, ears from $\mathrm{mAb}$-depleted or control mice were isolated, processed, and analyzed by flow cytometry. Treatment with anti-IFN $\gamma$ and anti-IL-12 promoted the differentiation of Th2 cells. il-4 mRNA expression (e-GFP ${ }^{+}$ cells) and IL-4 protein production (detected by hCD2 expression) were easily detectable $(7.9 \%)$ in the ear dermis of $\mathrm{CD}^{+}$ T cells (Figures 5A,C). Minimal IL-4 expression or production (0.4\%) was detectable in ear cells of similarly infected KN2/4get mice treated with a control $\mathrm{mAb}$ (Figure 5B) in line with the differentiation of Th1 cells in these mice. 4get/KN2 naive ears (0 h p.i.) showed detectable il-4 mRNA expression in $\mathrm{CD}_{4} 5^{+}$ but not in $\mathrm{CD}^{4} 5^{-}$cells and no IL-4 proteins as no huCD2 ${ }^{+}$cells were detected in either population, suggesting a lack of IL-4 production (Figure 5D). Infection did not change the frequency of cells transcribing $i l-4$ and no IL-4 production was observed 12 and $24 \mathrm{~h}$ after L. major infection (Figures 5E-G). These data suggest that ear skin mast cells transcribe the il-4 gene but do not produce detectable IL-4 proteins at steady-state conditions, and L. major does not induce IL-4 production in the ear dermis early during infection.

Taken together, these results demonstrate that during the first hours of infection, il-4 gene expression can be detected at the 


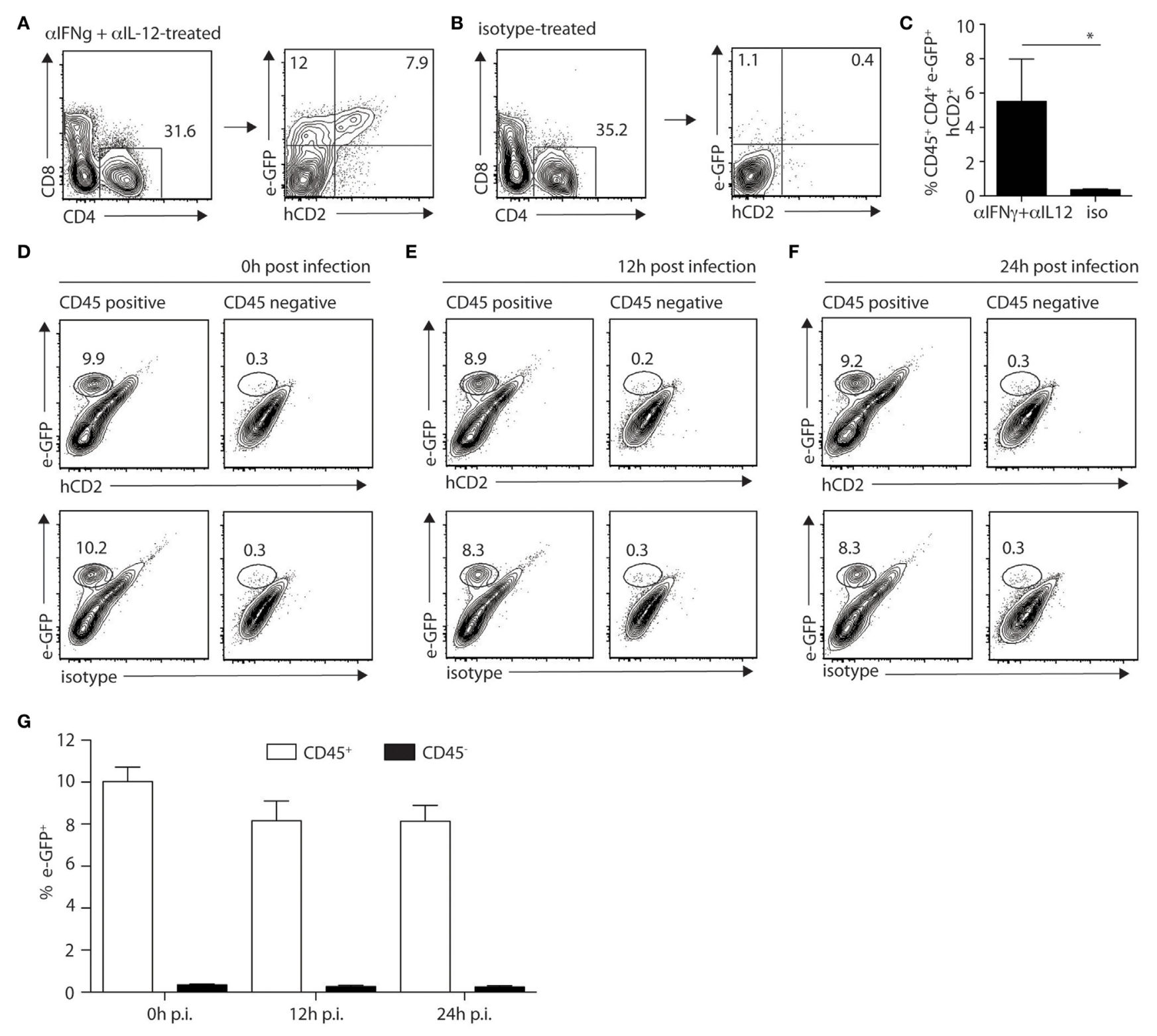

FIGURE 5 | IL-4 production is not detectable locally during the first hours of Leishmania infection in mice on the C57BL/6 genetic background. (A) C57BL/6 KN2/4get mice were injected intraperitoneally with anti-IFN $\gamma$ and anti-IL-12 24 and $2 \mathrm{~h}$ before and $48 \mathrm{~h}$ after infection with $2 \times 10^{5}$ Leishmania major i.d. in the ear. Four weeks p.i. ears were isolated and digested prior to labeling with anti-CD4 and anti-CD8 mAbs. CD4+ T cells were analyzed for the expression of il-4 detected by e-GFP and protein production of IL-4 detected by surface staining with a huCD2 mAb. (B) C57BL/6 KN2/4get mice were similarly infected but injected with an isotype control mAb at the onset of infection. Four weeks postinfection, IL-4 expression and production were analyzed by detection of e-GFP and huCD2 staining, respectively. (C) Bar graph gives the frequency of $\mathrm{CD} 45^{+} \mathrm{CD} 4{ }^{+}$eGFP+hCD $2^{+}$cells (means $\pm \mathrm{SD}$ of $3-5$ animals per group) ${ }^{*} p<0.05$. These are representative of three experiments. (D-F) C57BL/6 KN2/4get mice were inoculated into the right ear with $2 \times 10^{5}$ metacyclic L. major. Ears were recovered 0, 12 , and $24 \mathrm{~h}$ p.i., processed, and stained with CD45, human CD2, or its isotype control mAbs and analyzed by flow cytometry to detect the expression (e-GFP) and production (huCD2+) of IL-4. Representative flow cytometry profiles are shown (D-F) and (G) the bar graph shows the frequency of e-GFP+CD45+ and e-GFP+CD45- cells (mean \pm SD of 4 animals per group). Data are representative of three experiments.

infection site selectively in mast cell, but $i l-4$ mRNA expression was not modulated during L. major infection (analyzed at 0 , $4,12,16$, and 24 h p.i.). Furthermore, no IL-4 protein production was detectable in the ear dermis during the first $24 \mathrm{~h}$ after $L$. major infection.

\section{Local Neutralization of IL-4 Does Not Impair Th1 Development in Response to L. major Infection}

To further investigate if skin-derived IL-4 played a role in Th1 cell differentiation, C57BL/6 wild-type mice were infected 
with $2 \times 10^{5}$ L. major in the ear dermis following the protocol described in Figure 6A, which is similar to that described previously (21). Two weeks post infection, the frequency of $\mathrm{CD} 4^{+} \mathrm{IFN} \gamma^{+}$and $\mathrm{CD} 4^{+} \mathrm{IL}-4^{+} \mathrm{dLN}$ T cells represented in average 0.6 and $0.13 \%$ of total $\mathrm{CD}^{+} \mathrm{T}$ cells, respectively. These values were similar to those obtained in mice similarly infected but treated with a control mAb (Figure 6B). The levels of IFN $\gamma$ and IL-4 secretion in dLN cells stimulated ex vivo with UV-treated L. major 2 weeks after infection also showed no significant differences between the anti-IL-4 and control groups (Figure 6C). In line with these data, no difference in parasite load was observed between groups depleted or not of IL-4 at the onset of infection (Figure 6D). These results show that neutralization of IL-4 locally in the ear dermis during the first hours of infection at the site of infection does not have an impact on the development of the Type-1 immune response during cutaneous leishmaniasis.

\section{DISCUSSION}

The study of the early events leading to the differentiation of Th1 or Th2 cells is of importance and has relevance in the design of vaccines generated against pathogens inducing a specific Th type of immune response. IL- 4 and its signaling through interaction with the IL-4/IL-13 receptor has been described as an important cytokine favoring the differentiation of $\mathrm{CD}^{+} \mathrm{Th} 2$ cells and type 2 immunity (30). However, several lines of evidence suggest that IL-4 may also be involved in Th1 cell differentiation $(15-18,31,32)$. In this line, it was reported that following s.c. injection in the hind footpad of a very high dose $\left(2 \times 10^{7}\right)$ of L. major parasites, keratinocytes transiently upregulated il4 mRNA mostly within the first $16 \mathrm{~h}$ of infection. Blocking of IL- 4 at the infection site impaired IFN $\gamma$ secretion by dLN T cells 7 days later and increased IL- 4 secretion by dLN cells 1 week post infection (21).

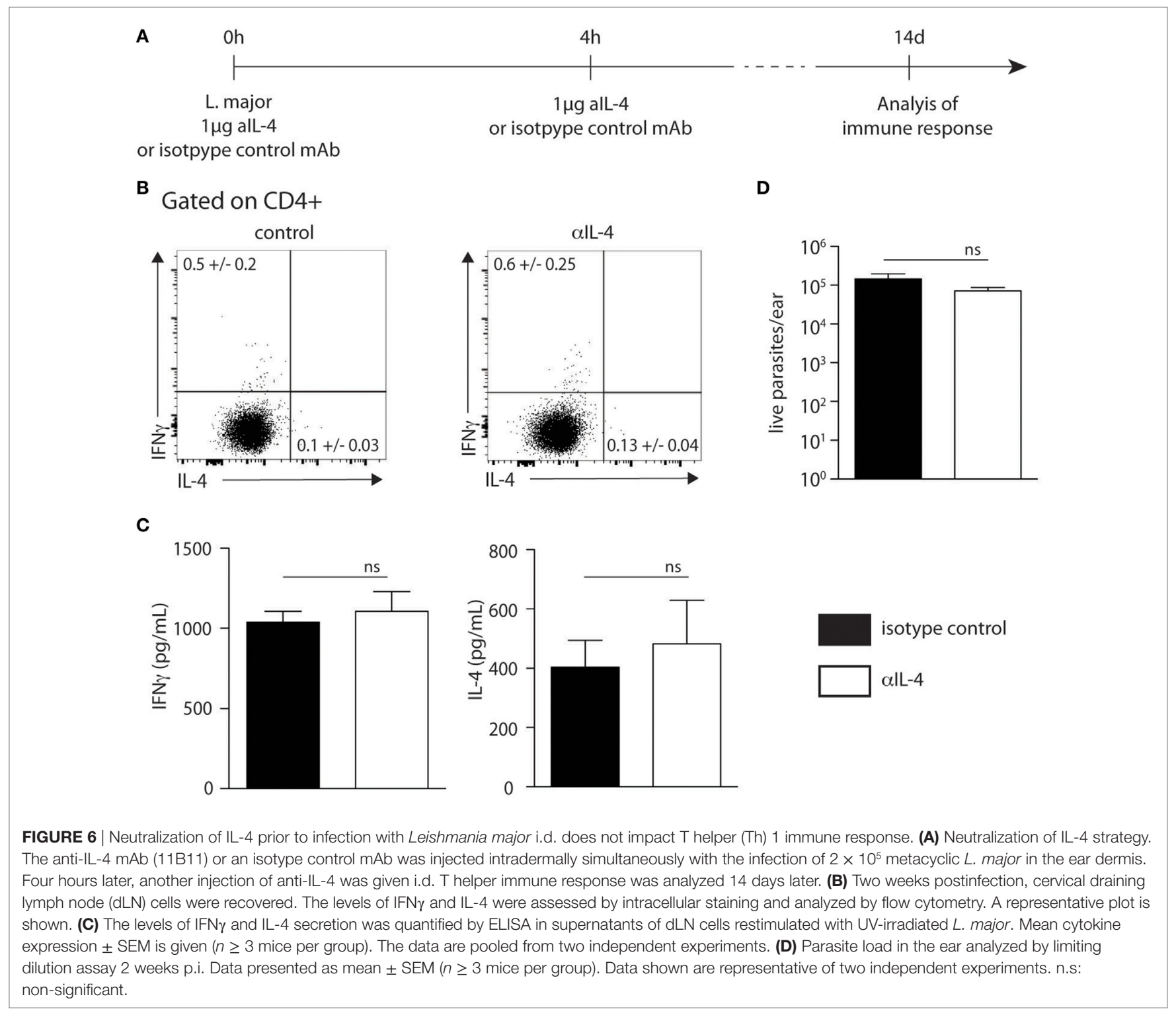


In an attempt to analyze if early after L. major inoculation, IL- 4 secretion by keratinocytes could act in an autocrine way on these cells locally during the first days of infection, we generated mice genetically deficient in the IL- $4 \mathrm{R} \alpha$ on keratinocytes. IL- $4 \mathrm{R} \alpha$ hemizygosity (-/lox) was used to increase the probability of the floxed allele deletion by the Cre recombinase (24). IL-4 was previously shown to act on structural components of keratinocytes in vitro, a process that could be linked to epidermal structural problems (33). We show here that naive KRT14 ${ }^{\mathrm{Cre}} \mathrm{IL}-4 \mathrm{R} \alpha^{-/ \mathrm{lox}}$ mice are viable and have a normal phenotype. Upon infection with L. major i.d. in the ear pinna with a low or with a higher dose of parasites, mice with impaired IL- $4 \mathrm{R} \alpha$ signaling on keratinocytes were able to resolve their cutaneous lesion, develop protective Th1 cells, and control parasite load. Similar data were obtained following infection of a higher dose of $L$. major subcutaneously in the footpad. These data demonstrate that following L. major infection IL-4R $\alpha$ signaling in keratinocyte does not impair wound healing and is not required for the development of a protective type-1 immune response.

To directly visualize if IL-4 expression was induced in keratinocytes following infection with L. major, we used the well characterized IL-4-GFP reporter 4get mice (22). We detected il-4-transcribing cells in the ear dermis of naïve C57BL/6 mice and the majority of the positive cells were mast cells and not keratinocytes. Mast cells are tissue-resident cells and it was previously reported that mast cells from $\mathrm{BALB} / \mathrm{c}$ mice constitutively express il4 mRNA at steady state (34). The detection of e-GFP ${ }^{+}$ (il-4 transcribing) mast cells in naïve ears detected here is thus in line with this study. Mast cell stimulation is required for these cells to secrete IL-4 protein. To verify if stimulated mast cells could be the source of the early IL-4 putatively present in C57BL/6 skin of L. major-infected mice, we used the KN2 reporter mice on the C57BL/6 genetic background, which allow the visualization of cells that produce IL-4 protein (23). Mast cells did not produce detectable IL-4 levels upon L. major infection within the first $24 \mathrm{~h}$ p.i. in KN2 mice. It was previously reported that C57BL/6 mice deficient in mast cells ( $\left.\mathrm{C} 57 \mathrm{BL} / 6 \mathrm{Cpa}^{\text {Cre }}\right)$ were perfectly able to mount a Th1 type of cell immune response following L. major infection (35). Together with our study, these results rule out a role for early mast cell-derived IL-4 in driving Th1 cell differentiation and resolution of lesion size and parasite load following L. major infection. In addition, il4 transcription was not detectable in keratinocytes during the first day of $L$. major infection.

It cannot be excluded that a few cells may locally express il-4 at low levels at steady state or upon L. major infection and that these cells were not detectable using L. major-infected 4 get mice. Nevertheless, as no detectable IL-4-producing cells were observed in the skin of infected KN2 mice the possibility of IL-4 driving Th1 differentiation following infection with $L$. major is rather unlikely.

Several factors may explain the differences observed between the present report and previous studies reporting a role for IL-4 in Th1 differentiation following $L$. major infection. First, the parasite dose injected differed in the two studies. Ehrchen et al. reported il-4 mRNA expression by keratinocytes during the first day after infection with a vey high dose $\left(2 \times 10^{7}\right)$ of $L$. major inoculated s.c. in the hind footpad (21). During their blood meal, sand flies deposit a much lower number of parasites ranging from $10-10^{4}$ and it was shown that the size of the parasite inoculum can have an impact on the immune response (36). Here, following infection of reporter mice with $2 \times 10^{5} \mathrm{~L}$. major, no detectable levels of il4 mRNA or IL-4 proteins were locally measured during the first days of infection. The parasite dose injected here is 100 times lower than that used in the study by Ehrchen et al., potentially explaining the differences observed. In addition, here, we used infective metacyclic L. major rather than stationary phase parasites to infect mice. Furthermore, the sensitivity of the microarray analysis used in the study by Ehrchen et al. is higher than that of the reporter system used here, as qPCR analysis can detect minute amounts of il-4 mRNA. The absence of IL- 4 proteins detected here suggests that if some IL-4 is produced locally following i.d. inoculation of parasites, it is in very low quantities.

A second major difference between the two studies is the site of parasite inoculation. Here, L. major was inoculated in the ear dermis, while in the Ehrchen's study it was injected subcutaneously in the hind footpad. Recruitment of innate cells to the site of infection was recently shown to differ whether $L$. major was inoculated in the hind footpad or in the ear dermis of mice, with a distinct impact on the local microenvironment at the site of infection (29). However, here, we show that irrespective of the site of infection, the absence of IL- $4 \mathrm{R} \alpha$ on keratinocytes in L. majorinfected mice did not have any impact on lesion development and immune response.

Distinct Leishmania species elicit different immune response. In addition, distinct $L$. major strains also have diverse virulence [reviewed in Ref. (28)]. This could have explained the differences observed in the two studies. However, mice on the C57BL/6 genetic background with total abrogation of IL-4R $\alpha$ on all cells were fully able to control lesion size and parasite load following either intradermal or subcutaneous infection with $2 \times 10^{5} \mathrm{~L}$. major of two different strains (LV39 or IR81), a process correlating with the development of functional Th1 cells in response to infection (here and unpublished data). Collectively, these data suggest that the difference observed in the two studies may not result from differences in the site of parasite inoculation or L. major strain virulence but rather come from differences in the parasite dose inoculated.

Distinct skin microbiota present in different animal facilities may also explain the differences observed between the previous and the present study as microbiota was shown to affect the immune response (37). This is, however, unlikely to be the explanation as the data presented here were obtained in two distinct laboratories with similar results. Furthermore, despite repeated attempts of blocking IL-4 locally using different parasite inoculation dose and injection scheme of anti-IL-4 mAb as well as distinct L. major parasite strains (here and unpublished data) we could not detect an impact of IL- 4 blockade on the immune response and parasite control between 14 and 21 days post infection.

Another study reported the importance of early IL-4 in $\mathrm{CD} 4^{+}$ Th1 differentiation (16). In this study, BALB/c mice infected with $2 \times 10^{5}$ L. major LV39 stationary phase promastigotes were treated with recombinant IL- 4 at the time and $8 \mathrm{~h}$ post L. major infection. Administration of a relatively high dose $(1 \mu \mathrm{g})$ but not of a lower dose $(0.1 \mu \mathrm{g})$ of IL- 4 instructed resistance in 
these otherwise L. major susceptible BALB/c mice. One major difference with the present study is that $\mathrm{BALB} / \mathrm{c}$ mice were used in that study. Furthermore, the dose of IL-4 injected locally may not correspond to cytokine levels present at the site of infection in L. major-infected C57BL/6 mice. If such levels of IL-4 protein had been present locally, it would have been detected here using the IL-4 reporter mice. Collectively, these and our data suggest that the early presence of IL- 4 may have a different impact on the development of Th1 response depending on the dose of parasite inoculated, the genetic background of the mice, and the local amount of IL-4 protein present at the site of infection.

Altogether, our data provide strong evidence that IL-4 signaling in keratinocytes at the site of infection or in general, is not required for the differentiation of Th1 cells following L. major infection and that IL-4 protein production at the onset of infection is not required for Th1 cell differentiation in L. majorinfected C57BL/6 mice.

\section{ETHICS STATEMENT}

All animal experimental protocols were approved by the veterinary office regulations of the State of Vaud, Switzerland, authorization 1266.6-7 to FT-C and performed in compliance with Swiss ethics laws for animal protection. All mouse experiments performed at the University of Cape Town were performed in strict accordance with the South African national guidelines, as well as the Animal Research Ethics Committee of the Faculty of Health Sciences, University of Cape Town (license no. 015/034). All efforts were made to minimize and reduce suffering of animals.

\section{REFERENCES}

1. Sacks D, Noben-Trauth N. The immunology of susceptibility and resistance to Leishmania major in mice. Nat Rev Immunol (2002) 2(11):845-58. doi:10.1038/nri933

2. Kaye P, Scott P. Leishmaniasis: complexity at the host-pathogen interface. Nat Rev Microbiol (2011) 9(8):604-15. doi:10.1038/nrmicro2608

3. Murray PJ, Wynn TA. Protective and pathogenic functions of macrophage subsets. Nat Rev Immunol (2011) 11(11):723-37. doi:10.1038/nri3073

4. Mosmann TR, Cherwinski H, Bond MW, Giedlin MA, Coffman RL. Two types of murine helper T cell clone. I. Definition according to profiles of lymphokine activities and secreted proteins. J Immunol (1986) 136(7):2348-57.

5. O'Garra A, Murphy KM. From IL-10 to IL-12: how pathogens and their products stimulate APCs to induce T(H)1 development. Nat Immunol (2009) 10(9):929-32. doi:10.1038/ni0909-929

6. Kopf M, Brombacher F, Kohler G, Kienzle G, Widmann KH, Lefrang K, et al. IL-4-deficient BALB/c mice resist infection with Leishmania major. J Exp Med (1996) 184(3):1127-36. doi:10.1084/jem.184.3.1127

7. Mohrs M, Ledermann B, Kohler G, Dorfmuller A, Gessner A, Brombacher F. Differences between IL-4- and IL-4 receptor alpha-deficient mice in chronic leishmaniasis reveal a protective role for IL-13 receptor signaling. J Immunol (1999) 162(12):7302-8.

8. Noben-Trauth N, Kropf P, Muller I. Susceptibility to Leishmania major infection in interleukin-4-deficient mice. Science (1996) 271(5251):987-90. doi:10.1126/science.271.5251.987

9. Noben-Trauth N, Paul WE, Sacks DL. IL-4- and IL-4 receptor-deficient $\mathrm{BALB} / \mathrm{c}$ mice reveal differences in susceptibility to Leishmania major parasite substrains. J Immunol (1999) 162(10):6132-40.

10. Noben-Trauth N, Shultz LD, Brombacher F, Urban JF Jr, Gu H, Paul WE. An interleukin 4 (IL-4)-independent pathway for CD4+ T cell IL-4 production

\section{AUTHOR CONTRIBUTIONS}

MD, BH, MG, KP, BM-S, and RH performed the experiments and contributed to their analysis. $\mathrm{BH}, \mathrm{MG}$, and $\mathrm{KP}$ made the figures. FT-C, RG, and FB contributed to the conceptual design and provided funding for this project. FT-C wrote the manuscript with comments from $\mathrm{BH}, \mathrm{MD}, \mathrm{KP}, \mathrm{RH}, \mathrm{RG}$, and $\mathrm{FB}$.

\section{ACKNOWLEDGMENTS}

The authors thank Ms. Yazmin Hauyon-La-Torre and Mr. Jess Coca for excellent technical assistance. The authors thank Dr. Stefanie Siegert of the UNIL flow cytometry facility for her assistance in flow cytometry imaging. The authors also thank Dr. Markus Mohrs for providing the 4get and KN2 mice and for discussions.

\section{FUNDING}

This work was financed by international co-operation grant IZLSZU3_14906 SNF and NRF grants to FT-C and RG. Part of the work was supported by the SNF grant 3100030_166651/1 to FT-C. Grants from the South African National Research Foundation (NRF) and from the Department of Science and Technology, South African Research Chair Initiative (SARCHi), and South Africa Medical Research Council (SAMRC) to FB, grants from the Department of Science and Technology (DST)/ South African National Research Foundation (NRF) for the Swiss-South African Joint Research Programme (SSAJRP), UID: 87399 to RG.

is revealed in IL-4 receptor-deficient mice. Proc Natl Acad Sci U S A (1997) 94(20):10838-43. doi:10.1073/pnas.94.20.10838

11. Kropf P, Schopf LR, Chung CL, Xu D, Liew FY, Sypek JP, et al. Expression of Th2 cytokines and the stable Th2 marker ST2L in the absence of IL-4 during Leishmania major infection. EurJ Immunol (1999) 29(11):3621-8. doi:10.1002/ (SICI)1521-4141(199911)29:11<3621::AID-IMMU3621>3.0.CO;2-Z

12. Mohrs M, Holscher C, Brombacher F. Interleukin-4 receptor alpha-deficient $\mathrm{BALB} / \mathrm{c}$ mice show an unimpaired $\mathrm{T}$ helper 2 polarization in response to Leishmania major infection. Infect Immun (2000) 68(4):1773-80. doi:10.1128/ IAI.68.4.1773-1780.2000

13. Radwanska M, Cutler AJ, Hoving JC, Magez S, Holscher C, Bohms A, et al. Deletion of IL-4Ralpha on CD4 T cells renders BALB/c mice resistant to Leishmania major infection. PLoS Pathog (2007) 3(5):e68. doi:10.1371/ journal.ppat.0030068

14. Hurdayal R, Brombacher F. The role of IL-4 and IL-13 in cutaneous Leishmaniasis. Immunol Lett (2014) 161(2):179-83. doi:10.1016/j.imlet. 2013.12.022

15. Mencacci A, Del Sero G, Cenci E, d'Ostiani CF, Bacci A, Montagnoli C, et al. Endogenous interleukin 4 is required for development of protective CD4+ T helper type 1 cell responses to Candida albicans. J Exp Med (1998) 187(3):307-17. doi:10.1084/jem.187.3.307

16. Biedermann T, Zimmermann S, Himmelrich H, Gumy A, Egeter O, Sakrauski AK, et al. IL-4 instructs TH1 responses and resistance to Leishmania major in susceptible BALB/c mice. Nat Immunol (2001) 2(11):1054-60. doi:10.1038/ni725

17. Hochrein H, O'Keeffe M, Luft T, Vandenabeele S, Grumont RJ, Maraskovsky E, et al. Interleukin (IL)-4 is a major regulatory cytokine governing bioactive IL-12 production by mouse and human dendritic cells. J Exp Med (2000) 192(6):823-33. doi:10.1084/jem.192.6.823

18. McDonald SA, O'Grady JE, Bajaj-Elliott M, Notley CA, Alexander J, Brombacher F, et al. Protection against the early acute phase of Cryptosporidium 
parvum infection conferred by interleukin-4-induced expression of $\mathrm{T}$ helper 1 cytokines. J Infect Dis (2004) 190(5):1019-25. doi:10.1086/422761

19. Yao Y, Li W, Kaplan MH, Chang CH. Interleukin (IL)-4 inhibits IL-10 to promote IL-12 production by dendritic cells. J Exp Med (2005) 201(12):1899-903. doi:10.1084/jem.20050324

20. Hurdayal R, Nieuwenhuizen NE, Revaz-Breton M, Smith L, Hoving JC, Parihar SP, et al. Deletion of IL-4 receptor alpha on dendritic cells renders BALB/c mice hypersusceptible to Leishmania major infection. PLoS Pathog (2013) 9(10):e1003699. doi:10.1371/journal.ppat.1003699

21. Ehrchen JM, Roebrock K, Foell D, Nippe N, von Stebut E, Weiss JM, et al. Keratinocytes determine Th1 immunity during early experimental leishmaniasis. PLoS Pathog (2010) 6(4):e1000871. doi:10.1371/journal.ppat.1000871

22. Mohrs M, Shinkai K, Mohrs K, Locksley RM. Analysis of type 2 immunity in vivo with a bicistronic IL-4 reporter. Immunity (2001) 15(2):303-11. doi:10.1016/S1074-7613(01)00186-8

23. Mohrs K, Wakil AE, Killeen N, Locksley RM, Mohrs M. A two-step process for cytokine production revealed by IL-4 dual-reporter mice. Immunity (2005) 23(4):419-29. doi:10.1016/j.immuni.2005.09.006

24. Herbert DR, Holscher C, Mohrs M, Arendse B, Schwegmann A, Radwanska M, et al. Alternative macrophage activation is essential for survival during schistosomiasis and downmodulates T helper 1 responses and immunopathology. Immunity (2004) 20(5):623-35. doi:10.1016/S1074-7613(04)00107-4

25. Spath GF, Beverley SM. A lipophosphoglycan-independent method for isolation of infective Leishmania metacyclic promastigotes by density gradient centrifugation. Exp Parasitol (2001) 99(2):97-103. doi:10.1006/expr.2001.4656

26. Allenbach C, Launois P, Mueller C, Tacchini-Cottier F. An essential role for transmembrane TNF in the resolution of the inflammatory lesion induced by Leishmania major infection. Eur J Immunol (2008) 38(3):720-31. doi:10.1002/ eji.200737662

27. Charmoy M, Brunner-Agten S, Aebischer D, Auderset F, Launois P, Milon G, et al. Neutrophil-derived CCL3 is essential for the rapid recruitment of dendritic cells to the site of Leishmania major inoculation in resistant mice. PLoS Pathog (2010) 6(2):e1000755. doi:10.1371/journal.ppat.1000755

28. Hurrell BP, Regli IB, Tacchini-Cottier F. Different Leishmania species drive distinct neutrophil functions. Trends Parasitol (2016) 32(5):392-401. doi:10.1016/j.pt.2016.02.003

29. Ribeiro-Gomes FL, Roma EH, Carneiro MB, Doria NA, Sacks DL, Peters NC. Site-dependent recruitment of inflammatory cells determines the effective dose of Leishmania major. Infect Immun (2014) 82(7):2713-27. doi:10.1128/ IAI.01600-13
30. Paul WE. History of interleukin-4. Cytokine (2015) 75(1):3-7. doi:10.1016/j. cyto.2015.01.038

31. Alexander J, Carter KC, Al-Fasi N, Satoskar A, Brombacher F. Endogenous IL-4 is necessary for effective drug therapy against visceral leishmaniasis. Eur J Immunol (2000) 30(10):2935-43. doi:10.1002/1521-4141(200010) 30:10<2935::AID-IMMU2935>3.0.CO;2-Q

32. Stager S, Alexander J, Carter KC, Brombacher F, Kaye PM. Both interleukin-4 (IL-4) and IL-4 receptor alpha signaling contribute to the development of hepatic granulomas with optimal antileishmanial activity. Infect Immun (2003) 71(8):4804-7. doi:10.1128/IAI.71.8.4804-4807.2003

33. Omori-Miyake M, Yamashita M, Tsunemi Y, Kawashima M, Yagi J. In vitro assessment of IL-4- or IL-13-mediated changes in the structural components of keratinocytes in mice and humans. J Invest Dermatol (2014) 134(5):1342-50. doi:10.1038/jid.2013.503

34. Gessner A, Mohrs K, Mohrs M. Mast cells, basophils, and eosinophils acquire constitutive IL- 4 and IL-13 transcripts during lineage differentiation that are sufficient for rapid cytokine production. J Immunol (2005) 174(2):1063-72. doi:10.4049/jimmunol.174.2.1063

35. Paul C, Wolff S, Zapf T, Raifer H, Feyerabend TB, Bollig N, et al. Mast cells have no impact on cutaneous leishmaniasis severity and related Th2 differentiation in resistant and susceptible mice. Eur J Immunol (2016) 46(1):114-21. doi:10.1002/eji.201545613

36. Kimblin N, Peters N, Debrabant A, Secundino N, Egen J, Lawyer P, et al. Quantification of the infectious dose of Leishmania major transmitted to the skin by single sand flies. Proc Natl Acad Sci U S A (2008) 105(29):10125-30. doi:10.1073/pnas.0802331105

37. Belkaid Y, Segre JA. Dialogue between skin microbiota and immunity. Science (2014) 346(6212):954-9. doi:10.1126/science.1260144

Conflict of Interest Statement: The authors declare that the research was conducted in the absence of any commercial or financial relationships that could be construed as a potential conflict of interest.

Copyright (c) 2017 Descatoire, Hurrell, Govender, Passelli, Martinez-Salazar, Hurdayal, Brombacher, Guler and Tacchini-Cottier. This is an open-access article distributed under the terms of the Creative Commons Attribution License (CC BY). The use, distribution or reproduction in other forums is permitted, provided the original author(s) or licensor are credited and that the original publication in this journal is cited, in accordance with accepted academic practice. No use, distribution or reproduction is permitted which does not comply with these terms. 